\title{
明治宮殿の建設経緯に見る表宮殿の設計経緯 \\ THE DESIGN PROCESS OF THE MEIJI PALACE'S MAIN HALL
}

\author{
山崎 鯛介* \\ Taisuke YAMAZAKI
}

\begin{abstract}
This paper shows the majestic design of the Meiji Palace's main hall was not decided at the date of commencement of work, but designed simultaneously with the progress of work. In the process of design, the ceiling of the hall was raised higher, and some western ornaments were added to the walling. An image of the ballroom was introduced in the design by Ito Hirobumi as the minister of the Imperial Household Agency, who insisted on the importance of holding evening parties in the palace as the diplomatic necessities.
\end{abstract}

Keywords : Meiji Palace, Modern Japanese-style, interior design

明治宮殿、近代和風、内部意匠

\section{1. 緒言}

明治 21 年に竣エした明治宮殿（正式には「宮城」）の建設事業は、 明治時代前半の日本の建築界における最大規模の国家的事業であり、 その建設経緯や建物の内容については、『明治工業史建築篇』(工学 会、昭和 2 年) を始め、これまでにも日本近代建築の通史を扱った著 作1などでたびたび紹介されてきた。明治宮殿に関する詳細な研究 論文としては、小野木重勝博士の2つの研究論文『明治洋風宮廷建築』 （相模書房、昭和 58 年）と『近代和風宮廷建築における和洋折克技法 に関する研究』(昭和 62 年度科学研究費補助金 [一般研究C] 研究成 果報告書) がある。前者では、主にボアンビルやコンドル設計の洋風 謁見所の意匠的特幑や造営過程で行われた地質調査や材料試験、基礎 に用いられた洋風技術について明らかにし、それらの技術史的重要性 を指摘している2。一方、後者では、構造技法や内装・外装に用いら れた「技法」に注目し、明治宮殿の和洋折哀が技術的側面においても 見られることを指摘しているぶ。このように、明治宮殿自体について はこれまで学術的に多くのことが明らかにされてきたといえる。

明治宮殿はまた、近年調查・研究が進んできた近代和風建築の歴史 において、その最初期の重要な建物として位置づけられることも多 い。特に「近代和風」という視点からは、宮中儀礼の場である表宮殿 に用いられた和洋折衷の内部意匠について取り上げられることが多
く、その柱・長押や格天井などに伝統的な和風意匠を用いながら、立 式で使用するために床を寄木張りとし、洋風家具やシャンデリアを備 えた和洋折蚛の内部意匠は、格の高い接客空間のあり方として後世の 建築にも大きな影響を与えたことが指摘されている4)。

このように後世の建築に与えた影響が大きいと考えられる以上、明 治宮殿自体の建設経緯や設計内容が具体的に明らかにされることは不 可欠と考えられる。しかし、あらためて明治宮殿を建造物として具体 的に把握しようとするとき、その建設経緯や設計内容についてはまだ 十分に明らかにされていない点も認められる。そこで本研究では、明 治宮殿の建設経緯や設計内容について詳細な検討を行い、そのデザイ ンの成立過程について明らかにした。またそれらを時代背景の中に位 置つけ、その意図についても併せて考察した。明治宮殿の造営過程は 計画段階も含めて長期にわたることが知られているが、以上のような 観点から、本研究では明治 16 年 7 月に木造計画に決定してから竣工 するまでの建設経緯を扱うこととする。また、明治宮殿は表宮殿・奥 宮殿など数多くの建物から構成されているが、本研究では大空間・和 洋折哀で知られる表宮殿の建物に注目して考察を行った。

明治宮殿の建設経緯を扱った既往研究としては、小野木重勝『明治 洋風宮廷建築』第 2 章第 2 節「皇居造営計画の変遷」があり、この中 では当初計画について、基本方針や設計体制・配分予算などが明らか 
にされている（pp.29-30）が、その後の経緯については概要紹介に留 まり、実際の事業がどのように進められたか、また表宮殿の意匠がど のような設計経緯で形成されたかについては触れられていない。稲葉 信子『木子清敬と明治 20 年代の日本建築学に関する研究』(東京工業 大学博士論文、平成元年) 第 3 章第 2 節「明治宮殿の造営」では、木 子清敬が表・奥宮殿の設計において極めて重要な役割を担ったことが 指摘されているが、設計経緯については「規模がきわめて大きい建築 であり、しかもその建設の経緯や建物の性格上、関与した官僚、動員 された技術者の数も多く、実際の設計がどのように進められていった のかを判断するのは難しい」(pp.48-49) とされている。実施過程にお ける木子の役割については、藤岡洋保、斎藤雅子、稲葉信子「東京都 立中央図書館木子文庫所収の明治宮殿設計図書に関する研究」『日本 建築学会計画系論文報告集』第 431号、pp.137-146）において、木子 文庫所蔵史料を用いてより詳細に検討されているが、設計経緯の全体 についてはまだ明らかにすべき点を多く残していると考えられる。

工事過程に関するものとしては、研究論文ではないが中村達太郎 「皇居御造営の頃」(『建築雑誌』昭和 10 年 7 月号) に、造営途中で大 変更があったことが書かれている。この中で中村は、宮内省庁舎の移 転、表宮殿の規模拡大、屋根咠材の変更などが明治 18 年 5 月に伊蕂 博文の指示によって行われたと述へている（p.116）が、小野不博士 は『明治洋風宮廷建築』第 3 章第 5 節「コンドルと宮内省庁舎計画」 の中で、『皇居御造営誌』の複数の記述を用いて宮内省庁舎の移転時 期に再検討を加え、庁舎の移転が明治 18 年 5 月ではなく明治 16 年 12 月 6 日の計画変更に合わせて既に内決していたと指摘している (p.97) s)。このことから、中村の発言に見られる表宮殿の設計変更に ついても、それそれの時期については再検討が必要と考えられる。

史料としては、宮内庁書陵部所蔵の『皇居御造営誌』（内匠案）と 『皇居造営録』(皇居御造営事務局)、そして東京都立中央図畫館木子 文庫所蔵の明治宮殿関係史料を主に用いた。『皇居御造営誌』は、明 治宮殿が竣エして 4 年後の明治 25 年 6 月に宮内省によって編筑され たもので、合計130冊に造営経緯や建物の仕様がまとめられている6)。 同史料は竣工記録としての性格が強いため、造営経緯とともに明治宮 殿の竣工時の意匠について知るのに最適な史料と考えられる。『皇居 造営録』は、宮内庁所蔵の皇居造営に関する公文啬で、ファイル約700 冊》といわれるが詳細は不明である。文書は明治 17 年 1 月に造営関 係文書の形式が制定 ${ }^{8)}$ されて以降のものがほとんどであるが、『皇居 御造営誌』に引用されていない資料も数多く含まれており、明治 17 年以降の設計経緯については『皇居御造営誌』よりも詳細に知ること ができる。木子文庫の明治宮殿関係史料については、史料が造営に際 してつくられたものであること、史料の大半（7845 点中 7524点）を 図面が占めること、内容については賢所・奥宮殿・表宮殿のほぼ全体 にわたり、詳細図も多数存在すること、作成時期の推定可能な史料が 点数の $40 \%$ を占めていることなどが藤岡らによって明らかにされて いる。木子文庫には『皇居造営録』よりも図面が多く残されていると 考えられることから、両者を同時に検討することで計画案の変更過程 を具体的に知ることができると考えられる。

明治宮殿の建物配置を示したのが図 1である9。既往研究を基に明 治宮殿の概要を述へておくと、「宮城」の敂地は旧江戸城の西ノ丸お よびその周辺で、表宮殿は西ノ丸、奥宮殿は山里、賢所は吹上、女官 部屋は紅葉山、宮内省庁舎は紅葉山下に建設された。宮殿の建物は公

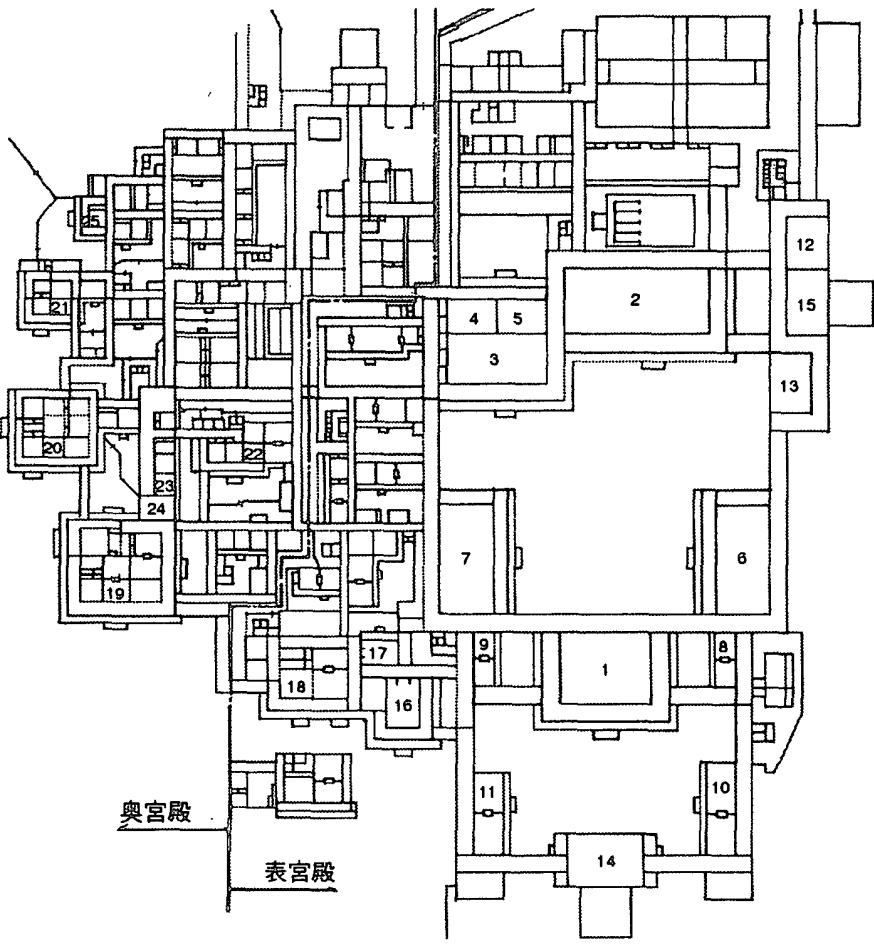

表宮既

1. 踢胃所

2. 鄂宾所

3. 伀席の間（広間） 10. 来脱帽所

4. 同（蝎人の間）11. 西脱帽所

5. 同 (小食所) 12. 北溜の間

6. 來溜の間 13. 南溜の間

7. 西溜の間
14. 御草寄受付の間
奥宮殿

19. 照上常御殿 20. 量后宮常御殿 21. 衁太后宮御休所 22. 宫御殿 23. 女官储所 24. 申口取合の間 25. 御霊代

\section{图1、明治宮殿竣工平面図}

用室としての表宮殿と住居としての奥宮殿およびそれそれの附属施設 から構成され、表宮殿と奥宮殿との境界は、御学問所と聖上常御殿の 間に設けられていたと考えられる。床面䅡は5,855.805坪10)であった と考えられ、構造形式は一部 111 を除いて木造平屋建てで、外観は入 母屋屋根を主とした和風意匠で建設された。内部意匠は表宮殿と奥宮 殿で異なり、表宮殿では謁見所や饗宴所などの主要建物 ${ }^{121}$ を大空間 とし、和風の軸組や格天井に床の寄木張りやガラス丞、縀帳などの洋 風要素を加味した独特の和洋折哀が用いられた。それに対し奥宮殿の 聖上常御殿や皇后宮常御殿は、暖炉や絨憅なども導入されているが、 基本的には床の間や明障子などを備えた和風建築として建設された。 皇居の造営計画については、既に以下のことが知られている。すな わち、明治 6 年 5 月 5 日に西ノ丸皇居（旧江戸城西ノ丸御殿）が焼失 した後、皇居再建の布達は翌 7 年に出されたが、政費節約などを理由 に計画は延期され、計画は明治 12 年に造営の議が再建されてようゃ く具体化した。これ以後は、敭地や表宮殿の構造・意匠形式をめぐつ て変更がくり返され、ボアンビル設計の赤坂仮皇居洋風謁見所の移築 を前提とした洋風謁見所移筑計画（明治 12〜13 年)、表宮殿・奥宮 殿のいずれも亦造とした木造宮殿計画（明治 13〜 14 年)、コンドル 設計の山里正殿と木造の吹上宮殿計画（明治14〜16年）などを経て、 明治 16 年7月に「木製假皇居」計画として実施することが決定した。 以後の実施過程では、明治 17 年 4 月 14 日に地鎮祭が行われ、主要建 物としては謁見所が最も遅く明治 21 年 5 月 23 日に竣エし、同年 10 月 27 日に皇居を「宮城」と改称した。 
なお、明治宮殿の各建物の名称については、竣工後の明治 21 年 12 月27日に正式名称が宮内省から布達され、たとえば造営中に「謁見 所」と呼ばれていた建物は「正殿」へ、「御学問所」と呼ばれていた 部屋は「表御座所」へと改称された。本研究では、造営中の史料を多 く扱う関係上、「謁見所」など造営中の名称を用いることとする。

\section{2. 建設過程で行われた事業規模の拡大と表宮殿の拡充}

皇居造営の事業計画については、小野木重勝『明治洋風宮廷建築』 の中で明治 16 年 7 月・8月に定められた当初の基本方針が紹介されて おり、工期は 5 年で竣工期限は明治 21 年 6 月とされたこと、明治 16 年度以降の事業予算は総額 250 万円で計画されたこと、事業区分は 4 区に分けられ、奥宮殿は第一区、表宮殿は第二区に属し、それそれの 工事担当者は第一区が木子清敬と和田善平で、第二区は中村一正と书 口正峻であったことなどが明らかにされている（pp.29-31）。しかし、 事業の最終結果について触れられていないため、実際の事業規模がど の程度のものであったかについては不明な点が多い。そこで本章で は、『皇居御造営誌』などを用いてまず事業の最終結果を明らかにし、 次に当初計画と最終結果の規模や予算・工程を比較することで、事業 計画の変化とその要因についても明らかにした。

平面計画については、基本方針が策定された明治 16 年 8 月 2 日に 最も時期の近い平面図として、『皇居御造営誌編算下調図』(以下『下 調図』）第 79 号図面（図 2、明治 16 年 8 月 4 日）がある。この平面図 を竣工建物の平面図と比較すると、奥宮殿については聖上常御殿、皇 后宮常御殿、女官候所などの平面が竣工建物とほほ同じと考えられ る。特に聖上常御殿と皇后宮常御殿については、木子文庫所収「第壹 区坪数及附属共調書」13)（明治 16 年 8 月 3 日）加ら、床面㮴について も竣工建物とほほ等しいと考えられる。これらの建物は、その後竣工

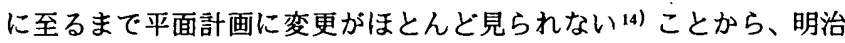
16 年 8 月の時点で平面がほほ決定していたと考えて良い。

それに対して表宮殿は、東西溜之間の有無、徯席之間の位置や階 数、謁見所迴りや侍従関係詰所の平面計画など多くの点で違いが見ら れ、また個々の建物についても謁見所、饗宴所、後席之間などは平面 が拡大されたと考えられる。床面積について見ると、木子文庫所収の 史料（無題、明治 16 年 8 月 9 日） ${ }^{15)}$ には表宮㩔の床面積が 2044 坪と 記されており、また宮内省庁舎の移転と同時に行われた表宮殿の規模 拡大について『皇居御造営誌・巻之七』に「謁見所 建筑ノ御口详有之建坪武千有余ノ増加 7 来ラシ」(明治 18 年 5 月 25 日 条）と、增加分の床面樌が約 2000 坪強であったと記されていること

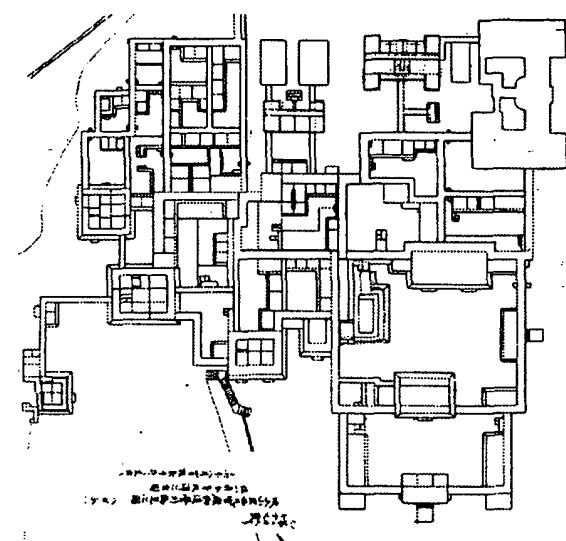

図2. 明治 16 年 8 月穴「木製假皇居」計画図 （『皇居御造営編某下調図·第武』所収）
から、表宮殿は明治 16 年12月の規模拡大によ り床面積がほほ倍增さ れたと考えられる。 次に予算について見 ると、当初の事業費は 先揭の総額 250 万円で 計画されたが、該決算 八総額八金四百拾五萬 三干六拾七円六銭四厘 ナリ」16) と、最終的に は415万3067円6銭4厘
に増額されたと考えられる。この予算の増額は、2度にわたる追加申 請に基づくと考えられる。1 回目（98万円）は明治 18 年 5 月 29 日に、 2 回目（48万 8232 円）は明治 19 年 12 月 21 日に皇居御造営事務局か ら宮内卿宛てに稟議が出され、後に裁可されている17)。またこの增額 分の費目について見ると、いずれも表宮殿の拡充にそのほとんどが使 用されたと考えられる。1回目は増額分の $85 \%$ （83万3千円）か「折 唡謁見所 7 始入喰宴所其他建築ノ御口澾有之建坪戴千余ノ增加 7 来 シ随テ諸材料其他ノ增費八勿論瓦屋根 器械 新設シ」とあるように、表宮殿の規模拡大に伴う材料費、屋根 咠材の変更、暖房設備の新設費など表宮殿の拡充にあてられ、2回目 は增額分の 81\%（39万4854円44銭 1 厘）が「外國装飾品購買費」や 「内國同断及電気燈ランフ費」とあるように、表宮殿の家具・装飾費 にあてられたと考えられる。

工期については、先揭のように当初の竣工予定が明治 21 年 6 月と して計画され、主要建物のうち最も遅い謁見所でも明治 21 年 5 月 23 日に「竣エ」したと『皇居造営録』に記されていることから、ほぼ 定通り進んたように見える。しかし、『皇居御造営誌』に記載された 各建物の「竣工」の日付を『皇居御造営誌・皇居御造営工程表』（以 下『エ程表』）からわかる工事の進渉状況と比較してみると、大エエ 事、壁張付工事、造作材の塗装工事などは「竣工」までに終了してい るが、腰壁・四分一・建具などの漆塗り、建具金物の取付、縀帳の製 作などは終了していないことがわかる。このことから、『皇居御造営 誌』に書かれた「竣エ」とは現場工事の終了を意味していると考えら れる。実際には表宮殿の追加工事と模様替えのために工事完了は明治 21 年 11 月下旬まで延期されたと考えられ、それは「新皇居宮殿向此 頃增工事或八模様替等被仰出候口々目今夫々着手致候処右八来ル十一 月下旬二八悉皆落成ノ見込二有之候間此段予及上申置候也」 ${ }^{18)}(\mathbf{\square}$ 不明、以下同じ) などの記述にうかがえる。また表宮殿の家具・装飾 品の完成は、「内部装飾ノ内現今計画中二係儿薷帳其他備付品二至テ 八猶数萬円ノ事業有之加ル二極メテ精エ 7 尽シ随テ多数ノ時日 7 要シ 候儀二付到底二十二年度二涉ラサレ八結了難相成候」19）とあるよう に、明治 22 年まで持ち越されたと考えられる。

以上のように、実際の事業では予算の増額や工期の延長を伴う大蝠 な計画変更が行われ、それは床面積の倍増、暖房設備・家具装飾の追 加など、主に表宮殿の拡充を意図したものであったと考えられる。

ところで、造営事業の予算や工期は当時の厳しい国家財政や明治 23 年の国会開設を前提 ${ }^{20)}$ に決められたと考えられ、予算增額や工期 延長は容易ではなかったと考えられる。実際の工事過程ではこうした 計画変更を実行するために、着工後の比較的早い段階から、当初は年 度単位で計画されていた工程や予算を工事の進渉に応して柔軟に組み 替えるなどのエ夫が取られていたと考えられる。

まず建物の着工時期について見ると、実際の工事では表宮殿の着工 時期が約 1 年間延期されたと考えられる。当初の着工予定は、『工程 表』所收「建築期限工程進歩一覧表」から、第一区は明治 17 年 7 月、 第二区は明治 17 年 10 月に「大工下拵一式」に着手予定となっている が、『程表』から建物の着工時期について見ると、明治 17 年 4 月 17 日の地鎮祭後、奥宮殿では聖上常御殿（明治 17 年 8 月 15 日）、皇后 宮常御殿（明治 17 年 8 月 26 日）などがまもなく木工事に着手したの に対し、表宮殿の主要建物は謁見所（明治18年9月1日）、饗宴所（明 治 18 年 9 月 6 日)、など、それよりも 1 年近く遅れた明治 18 年 9 月頃 
に木工事に着手されたことがわかる。また工事の進め方については、 表宮殿を含む第二区の着工延期を補うために明治17年から 18年にか けて奥宮殿を含む第一区の工事が当初の予定よりも前倒しで実施され たと考えられ、明治 18 年 12 月時点の工事の進渉状況を示した「建築 期限工程進歩一覧表」では、躯体工事を指す「軸建方小屋置渡」が、 第一区では7ヶ月分工事が前倒しされているのに対し、第二区では 5ケ月分遅れている。

予算についても、工事の進捗状況に応じた翌年度予算の前倒しや未 消化予算の翌年度への繰り越しが早くから行われていたと考えられ る。明治 17 年度予算については、「客歳五月以来諸般ノエ事 7 綝上ケ 施行候処現今二於テ八非常二進捗致シ就テハ十七年度予算額金六拾萬 円ニテハ凡金戴拾萬円余不足 7 生シ到底支弁難相成場合二至り（中 略)依テ八総額金戴百五拾萬円ノ内 7 以テ十七年度假皇居御造営費中 へ金武拾萬円增額トシテ御渡相成候様致度此段至急仰高裁候也」 ${ }^{21}$ ) として、当初予算の 60 万円に加えて工事の前倒しを理由に追加予算 として不足分 20 万円を前倒しする申請が出され、また逆に翌 18 年度 には、「十七年度中二於テ八支出ノ目途無之二付十八年度假皇居御造 営費中へ悉皆繰越目下使用致度」22) として、明治 17 年度の未消化予 算を翌 18 年度へ繰り越す申請が出され、それそれ認可されている。

こうした事業計画の変更には、宮内卿・伊藤博文が梁く関与してい たと考えられる。従来、造営事業と伊藤博文との関係に言及したもの としては中村達太郎「皇居御造営の頃」があり、ここで中村は明治18 年 5 月に「宮内卿伊藤博文さんが建築地實地检分の後、建築計画に 大々的変更を命ぜられたのです」(p.116) と述へている。しかし小野 木博士の指摘するように宮内省庁舎の移転と表宮殿の規模拡大は明治 16 年 12 月に計画されたと考えられ、明治 16 年 8 月 3 日に憲法調查か ら㷌国し、明治 17 年 3 月 21 日に宮内卿に就任した伊藤博文は、この 時にはまだ造営事業に関与する公的な立場にはいない。

伊藤博文と造営事業との関係については、宮内卿という公的な立場 から造営事業全体に哚く関わっていたと見る方が適切と考えられる。 伊藤が事業と直接的な関係を持つのは、就任直後の明治 17 年 4 月 12 日に皇居御造営事務局の職制が改定され、事務局が宮内卿の管轅下に 置かれてからと考えられる。就任翌月の明治 17 年 5 月 7日に出され た布達「皇居御造営事務章程」23) では、局中ノ事務シ大別シテ上下 二款卜ナス其上款八卿ノ裁決 上款に「建造物ノ位置結構 (ノ大体) ヨ定メ又ハ之ヨ变更スル事」と あることから、これ以降、建物の設計変更については宮内卿の許可が 必要になったと考えられる。伊藤は工程や予算の変更にも関与してい たと考えられ、明治 17 年 5 月 29 日に当初明治 21 年 6 月と定められて いた竣工期限を明治 20 年 8 月に前倒し24)する「落成期限ノ短縮」の 布達を出していることや、予算の増額や組み替えの申請の際に、事務 局から宮内卿へ稟議が出されていることなどにそれがうかがえる。

\section{3. 表宮殿の着工延期と設計変更による木造大空間の創出}

前章に示したように、表臽殿の着工時期は当初計画よりも約 1 年延 期されたと考えられる。『皇居造営録』や木子文庫所蔵史料にはこの 間に作成された木割書や仕様書、設計図面などが数多く含まれてお り、表宮殿の着工延期は設計期間の延長を意図したものであったと考 えられる。そこで本章では、『皇居造営録』と木子文庫所蔵史料を主 に用いて、この着工延期の期間に行われた設計の内容を明らかにし、 設計期間延長の意困について考察した。

平面計画については、表宮殿全体を描いた平面図として明治 17 年 4月14日の地鎮祭前後の様子を示すと考えられる「宮殿内間取図」 ${ }^{25)}$ と木工事着手直前の様子を示す表宮殿の全体平面図「第武区各所柱敷 座色分之図」 ${ }^{26)}($ 明治 18 年 8 月 2 日）があり、これらの比較から着工 延期の期間に行われた平面の変更内容について知ることができる。両 者を比較すると、建物の配置計画には大きな変化が見られないこと、 また建坪については、受付之間や南北溜之間、附立所など小規模な付 属室の床面積は拡大されているが、謁見所、饗宴所、後席之間、東西 溜之間など、明治 16 年 12 月に規模拡大されたと考えられる建物には 大きな変化が見られないことがわかる。

しかし天井高について見ると、謁見所、饗宴所、後席之間、東西溜 之間などではこの時期に天井高が揃って高く変更されたと考えられ る。表 1 は、「第武区各所矩計縮図」27)（明治 18 年 6 月 12 日）や木子 文庫所収の棒矩計図などを用いて、この期間における主要建物の室太 床面稓と天井高の変化をまとめたものである。これらの史料から、宣 内床面樌については謁見所と後席之間を除いて変化が見られないのに 对し、天井高については明治 18 年 1 月頃ほぼ同時に高く変更された と考えられ、喰宴所、後席之間、東西溜之間では明治 18 年 $3 \sim 4$ 月 に折上回数を増やして更に天井高が上げられたと考えられる。これら の建物は小屋組にトラスを用いた関係上、天井高はトラスの下弦材を 支える入側柱の長さに制限されると考えて良いか、その点から見て、 謁見所と饗宴所の天井高は設定可能な最大限まで上げられたと考えら れる。饗宴所の天井高は謁見所よりも若干高いが、竣工建物の棒矩計 図を見ると、謁見所と饗宴所の入側柱にはいずれも長さ約30尺 ${ }^{28)}$ (礎 石天端〜桁上端)の柱が用いられており、より天井の高い饗宴所では 入側柱の下に高さ1.6尺の「柱石」を挿入して対応していることがわ かる。このことから、謁見所と饗宴所の入側柱に用いられた約 30 尺 の柱は利用可能な限界寸法であったと考えねばならず201、天井高はそ の入側柱の限界長さまで㹡大されたと考えられる。また、表 1 からこ れらの建物に限って天井高の拡大と同時に柱太さが0.85尺角から 1 尺 角へと太く変更されだことがわかるが、その理由としては、謁見所と 饗宴所の天井高が 23 尺を超えるなど他よりも高く設定されたこと、 後席之間では 2 面、東西溜之間では 3 面を壁面としているのに対し、 謁見所と饗宴所では東・南・西の3面を全面開口部として壁面が北側 のみに限られ、軸組の補強が必要とされたことなどが考えられる。
表 1. 表宮殿の主要殿舎に見られる地顉祭時点かられ工事着手時点にかけての内部空間の規模の変化

\begin{tabular}{|c|c|c|c|c|c|c|c|}
\hline & \multicolumn{2}{|c|}{ 突内床面橲. } & \multicolumn{3}{|c|}{ 天井高（敂居上端～格縁下端） } & \multicolumn{2}{|c|}{ 柱断面寸法. } \\
\hline & 明治 17 年 4 月 & 明治18年8月 & 茲大前 $\left.{ }^{\circ} 1\right)$ & 明治18年1月 2) & 明治18年6月 & 明治 17 年 5 月 031 & 明治 18 年 5 月 $\left.0_{4}\right)$ \\
\hline 褐見所 & 128帖 & 160 帖 & 19.83尺(二重折上) & 23.5尺(二重折上) & 22.92 尺(二重折上) & 0.85 尺角 & 1.0尺角 \\
\hline 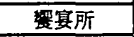 & 272 蛅 & 272蛅 & 19.9尺（折上） & 23.3 尺(折上) & 23.89 尺(二重折上) & 0.85 尺角 & 1.0尺角 \\
\hline 後席之間広間 & 182拈(1陵) & 144帖 & 15.88尺(平) & 20.0尺(平) & 21.2尺(折上) & 0.85 尺角 & 0.85 尺角 \\
\hline 東溜之間 & 175.5帖 & 175.5 帖 & 不明(平) & 17.3尺(平) & 18.83 尺(折上) & 0.8 尺角 & 0.8尺角 \\
\hline 西溜之間 & 175.5 蛅 & 175.5 帖 & 不明(平) & 17.3尺(平) & 18.83 尺(折上) & 0.8 尺角 & 0.8 尺角 \\
\hline
\end{tabular}

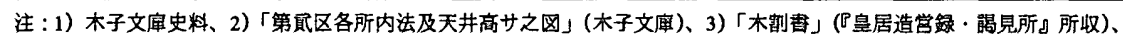
4)「第宣区負担御建物各所木割衣」(注 3) に同し)、( )内は格天井の形式を表す。
ところで、このように室内を無柱とす る木造大空間を実現するには構造的な配 虙が不可欠であったと考えられる。『皇居 造営録・日誌』(以下『日誌』)の明治 17 年 11月10日の条には「謁見所構造 7 始其他 未定之件二付課長以上之會議 7 開候事」 と書かれており、この時期にはこうした 
木造大空間を実現するため、構造形式などの技術的側面についても検 討されたと考えられる。この大空間の小屋組に洋風トラスが用いられ たことについては、小野木重勝『近代和風宮廷建築における和洋折哀 技法に関する研究』によって既に明らかにされている (pp.11-13) が、 その導入時期については不明な点が多く、今回史料を用いてその点を 検討したところ、実施過程については小屋組のわかる最も古い図面 (謁見所・明治 17 年 8 月 1 日） ${ }^{30}$ )において既に巻金物やボルトで金物 補強されたトラスが用いられていたこと、計画案も含めると明治 15 年 10〜 12 月頃の吹上宮殿計画 ${ }^{31)}$ では、梁間 5.5 間の内謁見所がトラ スで計画されていたことがわかった。トラスの正確な導入時期につい ては不明であるが、これらのことから見て、実施過程では早い段階か らトラスの使用が想定されていたと考えて良い。

また大空間を覆う大屋根については、その巨大な屋根荷重の処理も 技術的な検討課題であったと考えられる。中村達太郎「皇居御造営の 頃」では、屋根咠材についても他の変更と同様に伊藤博文の指示に よって当初予定されていた瓦革きが銅板咠きに变更されたと書かれて いるが、史料から屋根咠材の変更がこの着工延期の期間に行われてい たことが確認できた。すなわち木子文庫所蔵の「第武区屋根色分之 図」 ${ }^{32)}($ 明治 17 年 6 月 27 日）では「本瓦咠」で計画されていた表宮 殿主要建物の屋根が、明治 18 年の「築造仕法書」33)ではすべて銅板 瓦棒咠へと变更されている。この屋根咠材の変更は屋根荷重の軽量化 を意困したものであったと考えられ、屋根瓦土其外共重量試験之儀 上申」34（明治 17 年 8 月 11 日）には、「饗宴所御屋根本瓦咠二付瓦及 七咠土卜モ重量相斗裹二小屋組五分一之雏形製造シ石盤石 7 革立重器 比較候処別書之通二有之此段上申候也」と、屋根咠材の検討に際して 5 分の 1 の模型を用いた載荷試験が行われたことが記されている。

この時期には、これら大空間に使用する暖房設備の選定作業も進め られたと考えられる。機械暖房が設置されたのは謁見所、饗宴所、後 席之間、東西溜之間、内謁見所、南溜之間の 7 棟で ${ }^{35)}$ 、『皇居御造営 誌・宮殿室内暖温機械据付事業』によれば、導入された「独逸國製蒸 気空気暖温機械」とは、饗宴所北側のボイラー室で起こした蒸気を廊 下床下に設けたトンネルで各建物まで送り、各建物の床下に設けた 「暖温気室」で空気と混合させ、再度熱した混合蒸気を床の四隅から 室内に送り込むという方式であった。同書には暖房設備の選定経緯に ついて、「其機械ノ果シテ日本様家屋二適応シテ更二無害ヤ否 7 見認 ント欲シテ明治十七年七月五日在独逸國全権公使青木周蔵二鑑査 7 依 頼スル」と、明治 17 年 7 月にはカールローテ社を通じて欧米で使用 されている暖房設備の調查が始められ、最終的には、「謁見所東西溜 ノ間饗宴所後席ノ間等二装置ス可キ喛温機械ヨ独逸國漢堡カールロー デ商會同盟東京京橋区銀座刺賀商會二購買 7 命ス」 ${ }^{36)}$ と、明治 18 年 7月 11 日に購入約定書が交わされた経緯が記されている。

暖房設備の選定条件としては、まず大空間に適用可能であることが 求められたと考えられる。『皇居御造営誌・宮殿室内暖温機械据付事 業』には、機器の選定過程において、欧米で実績のある「空気暖房小 「蒝気暖房小「熱湯暖房」の長所・短所が比較された経緯が記されて いるが、最終的に「蒸気空気暖房」が採用された理由については、創 設費ノ高費二帰スルコト」としながらも、その長所として「空気配布 ノ均一ニシテ働キノー様ナルコト極メテ清潔ナルコト」と、大空間へ の適性を挙げている。それに対して「空気暖房」は、「室ノ廣濶ナル トキハ勢ヒ多数ノ『カロリフエヤ』ヨ要スルノ理由アリ依テ此法八宮
室ヨ暖温スルニ適用ス可ラザルモノトス」と指摘され、蒸気暖房」は 「管二温熱 7 與へルノミノ法ナルガ故高度ノ温気八常二管ノ近傍ノミ 二留滞最モ甚シトス故二室内到ルトコロ温気ヨ均一二配布シ難シ」 と、いずれも大空間を一様に暖房するのに不適であることが指摘され ている。選定条件としては、「日本建築への適応性」も重視されてい るが、この中には火災に対する配虑もあったと考えられ、「蒸気空気 暖房」の長所には「火災ノ憂ナキコト」も挙げられている。

\section{4 工事過程の設計変更による内部意匠の洋風化}

着工後の工事の進捗状況について、『工程表』を用いて検討すると、 表宮殿の主要建物では明治 19 年 12 月末には躯体工事がほほ終了し、 明治 20 年には内装工事に着手できる状態にあったと考えられる。ま ず大工工事を意味する「建築大工人足方」は、明治 19 年 12 月末の時 点で表宮殿の主要建物が作業工程の $85 \%$ を終了しており、翌月から

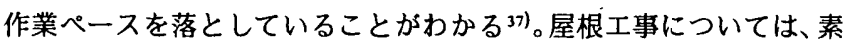
屋根工事を意味する「上家取設及盛換方」が明治19年12月に終了し、 屋根下地工事を意味する「屋根銅咠下柿革方」も明治 19 年 12 月に終 了していたと考えられる。暖房工事については、「第壹回暖温機械謁 見所外五ヶ所隧道棟化積工事」まり配管用の床下トンネルエ事が明 治 19 年9月 30 月に終了し、「焚試ハ十月一日ヨリ一週間卜ス」 ${ }^{38)}$ と あるように、翌10月1日には試運転が行われたと考えられる。一方、 内装工事について見ると、天井工事としては、「格天井漆塗方」や「折 上天井格天井共取解及取付方」などに明治 20 年 1 月から着手してお り、床工事では、床下への暖房装置の設置に伴う工事と考えられる 「根太仕直シ方仕增工事」が明治 20 年 2 月 21 日〜 3月 7日の期間に行 われ、4月からは「寄木張方」に着手したことがわかる。

『皇居造営録』所收の史料のうち、表宮殿の内部意匠に関するもの にはこの躯体工事から内装工事へと切り替わる明治 19 年末から明治 20年前半にかけて作成されたものが多いが、それらには「模様替」に 関するものが多く含まれていることから、この時期には表宮殿の内部 意匠が変更された可能性が高いと考えられる。そこで本章では、『皇 居造営録』所収の史料を用いてこの「模様替」前後の意匠についてで きるだけ明らかにし、またその変更の時期についても明らかにした。 着工時の表宮殿の内部意匠について具体的に知ることのできる史料 として、『皇居造営録』所収の「築造仕法書」がある。この「築造仕

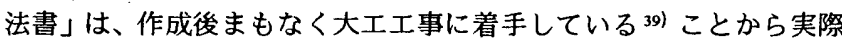
に使用された仕様書と考えて良く、主要建物の多くについて作成され ているため、表宮殿全体の考え方についても知ることができる。あく までも大工工事の仕様書であるため、装飾や仕上工事などに関する記 述はほとんど見られないが、軸組や天井形式など大工工事に係る部分 の内部意匠については知ることができる。

まず、この「筑造仕法書」と『皇居御造営誌』を用いて、これらに 記載された着工時の内部意匠と竣工時の内部意匠について表2にまと めた。表2から、着工から竣工に至るまでの工事過程において、内部 意匠では床を除く壁面と天井の意匠が設計変更されたことがわかる。 またその変更内容については壁面と天井とに大きく分けられ、壁面に ついては、入側建具は着工時に引違いで計画されていた建具が工事途 中で内開きのガラス扉に変更され、着工時に巾木（「築造仕法書」に は「靴摺」 ${ }^{40)}$ と記録）で計画されていたものが腰壁へと変更される など、より洋風色の強い意匠へと変更されたと考えられる。また天井 
については、着工時に「小組格天井」や「板張付」など木地仕上げの 意匠で計画されていたものが、漆塗格縁、錺金物、極彩色の張付模様 からなる装飾性の高い天井へ変更されたと考えられる。

次に、『皇居造営録』所收の史料を用いて内部意匠が変更された時 期について検討した。その結果、入側建具、腰壁、天井のいずれも明 治 20 年に入って決定され、直ちに工事に着手されたと考えられる。

入側建具については、木子文庫に明治 19 年 1 月・9 月作成の建具図 面41)があることから、この時期に建具意匠の検討が行われたと考え られる。建具意匠の変更が決定したのは、「謁見所製作建具仕様書」42 (『皇居造営録』所収)など竣工建物と同じ内容の仕様書が作成された 明治 20 年 $2 \sim 4$ 月と考えられ、3月には建具用の輸入ガラスが発注 ${ }^{43)}$ されるなど、変更後すくに製作にとりかかったと考えられる。

腰壁の導入時期はやや遅く、明治 20 年 $5 \sim 6$ 月に決定したと考え られる。腰壁の導入経緯については滞欧中の片山東熊と事務局との電 報 ${ }^{44)}$ から知ることができ、「劉宴所ノミ腰羽目ノ高ヨ八十五サンチ メートルニセヨウ木ハ御随意二希フ」(片山 $\rightarrow$ 毫務局 : 明治 20 年 5 月 11日)とあるように腰壁はまず飨宴所に導入されたと考えられる。す ヘてての主要建物に腰壁が導入されたのは、事務局と京都出張中の荒川 新一郎との間で交わされた電報45) から、明治20年6月頃と考えられ、 電報には「謁見所腰羽目高式尺八寸東西溜之間式尺二改正ス」(事 務局 $\rightarrow$ 荒川: 明治 20 年 6 月 21 日)、「後席廣間腰羽目高武尺八寸同 所婦人室小食堂等巾木高サ壱尺戴寸東西溜リノ間腰羽目高サ四尺四寸 各室卜壬改正ス」（事務局 $\rightarrow$ 荒川：明治 20 年 6 月 24 日）とある。

天井意匠について見ると、謁見所では明治 19 年には小組格天井以 外の意匠が检討され始め、明治 20 年 2 月に張付天井への変更が決定 したと考えられる。それは、木子文庫の史料に二重折上の平の部分に 2 種類の格間 (3.1 尺四方と6.6尺四方) を混用した計画案（明治 19 年 1月10日）など3 種類の天井伏図 ${ }^{46)}$ が含まれていること、『皇居造営 録』に「呈正二十年二月御模様替增費」47) として「間内格天井小組 之所張枠二御模様替」と記されていることにうかがえる。また謁見所 では、明治 20 年 2 月 10 日に印刷局へ張付模様紙の製作が発注された と『皇居御造営誌・天井張打出紙其他製紙事業』に記されていること から、張付天井への変更決定とほほ同時に製作が発注されたと考えら れる。一方、東西溜之間では、一度「板張付」で着エされたものが、 工事途中で張付天井に変更されたと考えられる。「東西溜之間鏡天井 板知木仕拵仕様書」48）に「知板桧柾目厚壱分」とあることから、明 治 19 年 10 月にはいわゆる板違格天井で計画され、『エ程表』によれ ば同年 12 月 1 日にはその工事「東西溜之間鏡天井知木仕据一式工事」 に着手している。しかし、明治 20 年 3 月には竣工建物とほほ同じ張 付天井の仕様書「東西溜之間及廊下共格天井張付仕様曺」49) が作成 され、3月1日にはその工事「東西溜ノ間格天井張付枠模様替方」に

\section{表 2. 表宮殿の主要建物に見られる普工時と竣工時の内部意匠の比䡆}

\begin{tabular}{|c|c|c|c|c|c|c|}
\hline & & 床仕上 & 入侧建具 & 曈面 & 暒仕上げ & 天井形式 \\
\hline \multirow{2}{*}{ 喝見所 } & 鄫工時。 & 答木㮛 & (換及硝子户 & 佂挧: & 出照有塈其張付 & 二重折上小組格天刑 \\
\hline & 榙工時 & 筞木馒 & 猡付的子開户 & 腰羽目 & 棅子張 & 二重折上盗格天井張付 \\
\hline \multirow{2}{*}{ 繁宴所 } & 蓎工時 & 䨐杰巽 & 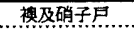 & 㔀热: & 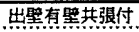 & 二重折上格天并板張付 \\
\hline & 婈工㭙 & 寄木張 & 䝢付硝 & 复羽具 & 轧子張 & 二重折上望格天井张付 \\
\hline \multirow{2}{*}{$\begin{array}{l}\text { 後席之閔 } \\
\text { (鹿) }\end{array}$} & 着工睦 & 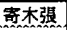 & 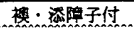 & 䣋撌* & 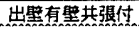 & 折上格天并板㖘付 \\
\hline & 摔工時 & 笴木張 & 腰付硝子㑭户 & 盟䈳自 & 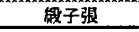 & 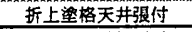 \\
\hline \multirow{2}{*}{ 東溜之間 } & 急工帱 & 寄木張 & 無良户” & 靴㥜。 & 出䉆有照共張付 & 折上格天 \\
\hline & 姫工時 & 管木馒 & 腰讨硝 & 䁙羽目 & 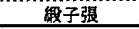 & 折上塰格天井張付 \\
\hline \multirow{2}{*}{ 西瀷之間 } & 着工睦 & 寮木镸 & 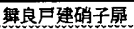 & 跳翼 & 出慜有壁其張付 & 焎上濹格天井板腲姇 \\
\hline & 琖工时 & 青木張 & 缕付硝子開户 & 喓羽目 & 諓子張 & 格天” \\
\hline
\end{tabular}

注 : 着工時の意匠は「築造任法韋」による。また竣工時の意匠は『皇居御造営䄊』による 着工時の休仕上は「大工手間人足内訳概算調」(明治 18 年、『皇居造営録』所収)による

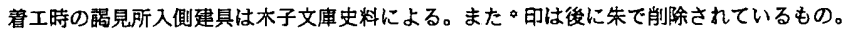

着手したことが『工程表』からわがる。

なお、壁面意匠の洋風化については入側建具や腰壁の他に、軸組に 加えられた変更にも見ることができる。『工程表』には明治 20 年 2 4月に謁見所・饗宴所・後席之間に「御模様替二付柱面取其外工事」 が行われたと書かれているが、この「柱面取」は竣工建物の仕様書に ある「唐戸面取」を指すと考えられる。これは、柱以外に鴨居の下端 や方立にも施されている50)ことから、入側建具が引違いから開き屝 へと変更されたのを受け、柱や鴨居・方立を洋風の建具枠に見立てた 変更と考えて良い。また、当初真壁で計画されていた東西溜之間の壁 面が大壁に変更されたのもこの時期であったと考えられ、東西溜之間 それそれについて「中之間内法リ長押天井長押卜モ御模様替二付木削 リノ上返木」 ${ }^{51}$ （明治 19 年 12 月 21 日）と、真壁の建物を大壁へと改 修したことを示す史料が遺されている。

ところで、着工時の壁仕上げについては、表2に示すように「築造 仕法書」には「出壁有壁共張付」とあるのみで、張付の素材や模様に ついては書かれていない。「総テ絵画或八彩色等二係ル事八博物館長 山高信離専ラ之习指揮セリ」 ${ }^{52)}$ とあることから、明治宮殿の装飾が 本格的に検討されたのは、山高信離が嘱託として参加した明治 18 年 6月8日以降になってからと考えられ、着工時にはあまり詳細に決定 されていなかったことも考えられる。

織物の使用が検討され始めたのは、明治 19 年7月頃と考えられる。 織物事業を担当した農商務技師・荒川新一郎が正式に啒託となるのは 明治 20 年 5 月 12 日 $^{53)}$ であるが、別の史料には「御省四等技師荒川 新一郎へ皇居御造営御間内装飾取調ノ儀依嘱致度候」(明治 19 年 7月 22 日） ${ }^{54)}$ とあることから既に明治 19 年 7月の段階で事務局から協力 を打診されていたと考えられ、また同年 7月 20 日には京都で織物産 業の近代化に取り組んでいた京都府織殿御用掛の稲畑勝太郎にも「皇 居御造営装飾用織物染色取調」が依啒されている55)。また、『日誌』 に「権少技長荒川新一郎出所二口稲烟勝太郎等口宮殿内装飾織物之義 面談之処折柄京都織殿員近藤德太郎上京御用伺之為来局口居二付織物 為考案御場所内へ同行一見セシメタル事」（明治 19 年 8 月 1 日）と、 8月 1 日には既に荒川と稲畑が面談したと書かれていることから、翌 8月には具体的な検討段階に入っていたと考えられる。表宮殿の壁仕 上げを織物張付にすることが最終的に決定したのは、片山東熊と事務 局との電報に「時日ナシ壁上へ皆壱打緞子ヨ用ユルニ決ス」(事務局 $\rightarrow$ 片山: 明治 20 年 4 月 2 日）とあることから、明治 20 年 4 月 2 日で あったと考えられる。織物の製作は、荒川新一郎が正式に事務局と契 約を結んた 5 月から始められたと考えられ、正式採用の理由にも「頃 日右装飾取調向八勿論現業頗儿頻繁ノ秋二際シ専ラ従事不致候テ八差 支モ不少候二付即今ヨリ来ル八月中迄當局へ借用ノ上該事業専担為致 候様致度候條御繰合御示命相成度此段及御照會候也」 ${ }^{56)}$ と、 5 月から 8 月にかけて業務が多忙を極めるであろうことが書かれ、また 5 月 2 日には、荒川新一郎から京都の織物業者である川島甚兵衛へ「イトノ ヨコイシテヨロシ」（明治 20 年 5 月 2 日）との電報も打たれている。 なお、織物以外の洋風の壁仕上げとしては、壁紙貼りも検討された と考えられる。『印刷局沿革録』(印刷局、明治 40年) 37)の明治 19 年 度の項には、「是年皇居御造営用壁紙 7 製造ス」(p.126) といった記 述が見られ、また『日誌』にも、「印刷局以縁紙見本四冊壁紙少切レ 四枚壁紙見本壱冊等為参考送リ来ル二付」(明治 19 年 12 月 8 日条)と 記されている。この明治 19 年に製造された「皇居御造営用壁紙」は、 
明治20年10月に製作が発注され表宮殿の廊下に実際に使用された壁 紙 ${ }^{58)}$ とは製作時期が異なることから、室内か廊下用の試作品であつ た可能性が高いと考えられる59)。

\section{5. 内部空間の壮麗化と宮中夜会の重視}

第3章、第4章で見たように、明治宮殿の特幑として知られる表宮 殿の大空間・和洋折哀意匠からなる内部空間は、着工当初から決定し ていたのではなく、地鎮祭後の工事過程において、天井高の拡大や内 部仕上げの装飾化・洋風化を意図した設計変更などが加えられて形成 されたものであったと考えられる。本章ではこれらのことを踏まえ、 家具デザインの考え方や竣工後の使われ方を含めて見ることで、この 内部空間の壮麗化が何を意図して行われたかについて考察した。

表宮殿の洋風家具については、『明治工業史建築篇』や『鳳闑』 （上野竹次郎編、大正 14 年、興文堂）などの刊行本に揭載された写真 がよく知られており、写真を見る限り、ルネサンス風（饗宴所）、バ ロック風（後席之間）、ロココ調（婦人之間）など、純洋風の様式家 具が用いられている。これらの写真の撮影時期については不明な点が 多く、必ずしも竣工時の状態を示しているとは限らないが、明治 21 年10月10日の皇居御造営残業掛への引継に際してつくられた「装飾 具明細書」60) に、「大食器棚（左右二織 （いずれも筤宴所）や「鏡」3面、「鏡台」3個（いずれも後席之間）と あることから、鏡台などの大きな家具は竣工時のものと見てほほ間違 いない。周知のように、これらの家具はドイッのカールローデ社を通 して購入された 61) か、カールローデ社が洋風家具導入の際に描いて いたイメージについては、『皇居御造営誌・家具装置事業』第 1 巻所 収の「大日本東京皇居御造営御装飾品二係儿説明書」(以下「家具計 画書」）および「家具及敷物約定書附属書」（以下「約定書」）62）に窥 うことができ、ここでは謁見所、饗宴所のように使用目的が明確でな い部屋に対して、東溜之間は「吸煙室及七骨牌室（Smoking and card Room : 英語は原文写 $\left.{ }^{63)}\right)$ 」西溜之間や婦人室は「舞踏室 (BallRoom)」 と位置つけ、また後席之間（Drawing room）には「合奏二用ユル大ナ ル『ピアノ』を計画している。つまり、カールローデ社は家具計画 のイメージとして欧米風の「夜会」を想定し、表宮殿の洋風家具はそ れに基づいて導入されたと考えられる。

これら洋風家具の導入が決定した時期については、内部意匠の洋風 化に先立つ明治 19 年の後半であった可能性が高いと考えられる。理 由としては、片山が渡欧した明治 19 年 12 月 31 日の時点では、饗宴 所以外の部屋はまた洋風家具の使用が確定しておらず(4)、よってカー ルローデ社への家具計画の依頼時期も明治 19年12月からそれほど湖 らないと考えられること、また宮中における夜会の開催は、皇后が洋 装化を天皇から許可された明治 19 年 6 月以降にならないとほとんど 実現性がないことなどが挙げられる。また、第4章で示したように、 壁仕上げへの織物張付の適用は明治 19 年 7 月以降に検討され始めた と考えられるが、滞欧中の片山東熊と御造営事務局との間で交わされ た電報に、「壁張附織物色合八（中略）尤モ右各室特二謁見所後席之 間西溜ノ間ノ三室八家具二相当セ子バナラヌ」(明治 20 年 4 月 5 日 : 片山 事務局) とあることから、織物張付・洋風家具ともにお互いの 調和を考虑して同時期にデザイン・色彩が検討された可能性が高い。

一方、竣工後の表宮殿で行われた宮中儀礼の内容について、『明治 天皇紀』（宮内庁、昭和 47 年ほか）を用いて検討すると、年中行事の
「朝儀」と不定期に行われた「大典」とでは、内容が大きく異なって いたと考えられる。すなわち、「朝儀」である新年宴会（1月5日）、 紀元節賜宴 (2月11日)、天長節賜宴（11月3日）の三大節賜宴では、 皇后を始め婦人は不参加で、賜宴は和食昼餐で行われたのに対し、 「大典」として行われた憲法発布式（明治22年 2 月 11 日）、皇紀 2550 年紀元節 (明治 23 年 2 月 11 日) 、大婚 25 年祝典 (明治 27 年 3 月 9 日)、 皇太子御成婚の礼（明治 33 年 5 月 10 日）、ガータ一勲章捧呈式（明 治 39 年 2 月 20 日）は、皇后を含め夫人同伴で行われ、賜宴は大規模 な洋風の夜会形式で行われている(5)。つまり、カールローデ社の家具 計画書で想定された宮中夜会の形式は、明治初頭から行われていた三 大節賜宴などの朝儀には適用されず、明治宮殿竣工後に初めて行われ るようなった大典において適用されたことがわかる。

以上のことから見て、洋風家具も含め、表宮殿に見られる壮麗な内 部空間は、竣工前には前例のなかった「宮中夜会」を想定して創出さ れたものと考えて良いと思われる。このような宮中夜会の開催は、宮 内卿時代の伊藤博文が強く主張した宮中政策であったことが知られて いる ${ }^{66)}$ か、このことと伊藤博文の造営事業における権限の強さ、設 計変更の時期などを考え合わせると、表宮殿の壮麗な内部空間は、宮 内卿・伊藤博文に代表される明治新政府の「近代の宮殿」に対する考 え方が強く反映したものとして位置づけることができる。

\section{6. 結論}

本稿では、宮内庁所蔵史料や木子文庫所蔵史料を用いて、明治 16 年7月以降の明治宮殿の建設経緯に見られる表宮殿の内部空間の設計 過程を分析し、以下のことを明らかにした。

事業は当初、工期 5 年・予算 250 万円で始められたが、計画変更に より最終的に事業費は 415 万 3067 円 6 銭 4 厘に増え、工期も明治 22 年度まで延長された。増額分のほとんどは表宮殿の拡充に費やされ、 床面積の倍增、暖房設備・家具装飾の追加が行われた。また計画変更 を実行するための工夫として、着工後の早い時期から着工延期や工事 の前倒し、予算の前倒しや繰り越しなど、工程や予算が工事の進捗状 況に応して柔軟に組み替えられた。

こうした計画変更には、宮内卿・伊藤博文が公的な立場から深く関 わっていたと考えられる。特に「皇居御造営事務章程」が出された明 治 17 年 5 月 7 日以降は建物の設計変更に宮内卿の許可が必要になり、 また予算・工程の変更にも宮内卿の許可が必要とされた。

実際の工事では、表宮殿では着工延期によって設計期間が約 1 年間 延長され、明治 17 年 4 月から明治 18 年 9 月頃の期間に行われた設計 変更では、天井高の拡大による内部空間の拡大とその大空間に必要と される棬造への配虑、暖房設備の選定などの技術的検討が行われた。 また、躯体工事から内装工事に切り替わる明治 19 年末から明治 20 年 には表宮殿の内部意匠が設計変更され、壁面と天井がより装飾的で洋 風色の強い意匠へと変更された。

以上のことから、表宮殿の内部意匠は着工時に計画されたのではな く、造営過程の設計変更によって形成されたと考えられる。また内部 意匠の壮麗化は、ドイッから輸入された洋風家具とともに、それまで 前例のなかった宮中夜会を想定したものであったと考えられ、このこ とは宮中夜会の開催を重視した宮内卿・伊藤博文の宮中に対する考え 方とも一致する。これらのことから、表宮殿の壮麗な内部空間には、 伊藤に代表される新政府の考え方が反映していると考えられる。 
[謝辞] 本稿を作成するにあたり、宮内庁書陵部の小坂敏郎氏 (当時) には史料 閲覧に関してお世話になりました。記して謝意を表します。

[註]

1)明治宮殿を取り上げた通史には、桐敷真次郎『明治の建築に(日経新書、昭和 41 年、pp.95-98)、村松貞治郎・近江栄編『近代和風建築』(鹿島出版会、昭 和 63 年、pp.114-117) がある。近代和風建筑に関する研究論文では、藤原惠 洋『日本近代建築に扮ける和風意匠の歷史的研究』(東京大学博士論文、昭 和 62 年）で明治宮殿を取り上げている。研究論文以外で表宮殿の内部意匠 を論したものに、桐敷真次郎「宮即建策の『種』一明治宮殿の室内装飾と二 代川島甚兵衛一」(『KAWASHIMA』12号、昭和 58年9月、pp.15-18) がある。 いずれも本研究とは使用史料、考察の目的が異なると考えられる。

2)「前者 (明治宮殿 : 筆者註) は最終的には木造宮殿となったか、その計画過 程でしばしば洋風宮殿の計画が試みられ、その技術的成果は、一般建築界の 発展にも少なからぬ影響を及ほした」(p.2)

3)「表宮殿における洋風の導入の仕方をみると、様式やデザインの源泉を海外 に求めるといった皘極的な建筑的要求によるものではなく、表宮殿の構造あ るいは機能上の必要性から生したものとみてよいであろう」(p.19)

4) 18 日本銀行本店』（明治二十九年）の貴筫室に、表宮殿と同様に和洋折哀技 法に基つく室内意所が採用されている事実は、この様式が正式な接客空間に ふさわしいものとして認知されていたことを物語っている」(大川三雄「和 風大邱宅に見る近代の諸相」(『月刊文化財』平成 13 年 10 月、p.11) なと

5）『皇居御造営誌編策下調图』第 84 号図面（明治16年12月14日）は宮内省 庁舎移転後の状態を示しており、付箋に「明治十六年十二月六日ヨリ十日マ テニ目論見同十一日年前第十一時上局へ差出同十三日上局ヨり該因被下付直 二稊引布へ製シ同十四日午后二時上局へ差出シタル原困」とあることから小 野木博士の説と一致する。

6）同史料には附属編として、明治初年からの計画図をまとめた『皇居御造営 誌編箘下調図』(2冊)、主に設借図に開する『皇居御造営諸御建物其他明細 図』(34冊)、内部装飾の縮小色絵図をまとめた『皇居御造営内部諸装節明細 図』(32冊) が作成されている(いずれも宮内庁所藏)。

7）宮内庁書陵部図書課公文書係への間き取りによる。本研究では、建物の設 計内容を知ることができるものを中心に 117 冊閲覧した。

8)このことについて『皇居御造営誌・巻之六』には、「工事着手及七落成上申 八儀八從来（第何号伺済人件明何日着手) 等余簡易二過クルラ以テー々其

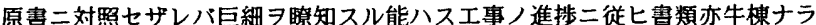
ンヨ虑リ着手及七落成ノ上申二限り自今別紙害式二拠ラシム又九月二十七日 二至リ購買ノ諸物品納付済ノ上申書式モエ事着手落成上申ノ式二涑拠七シ 厶」(日月治 17 年 1 月 21 日条) と書かれている。

9)『皇居御造営誌編筑下調図』所取「謁見所以下地之間図」(表宮殿、日付な し)「常御殿以下四百分一」(奥宮殿、明治 18 年 8 月調）を用いて作成した。 これらは内容から最終园面と考えられ、竣工時に最も近いと考えられる。

10）『明治工業史建築篇』(p.424)に明治末年の「本館」の延坪として記載 されている。この「本館」がとこままで指すのか不明である。また現時点で は竣工时の建物の床面積を正確に把握でるる史料を見出していない。

11）御学問所、侍從武官詰所は木造 2 階建て、䊈宴所北側のボイラー室は煉瓦 蔵で建設されたと考えられる。

12）本稿では、明治宮殿の代表的な特徵である大空間・和洋折哀意匠を持つ謁 見所、喰宴所、後席之間広間、東西溜之間の 5 つの建物を中心に考察を進め るため、これらの建物を便宜的に「主要建物」と呼ふことにする。

13）木子文庫所収「第壹区坪数及附属共調書」(史料番号・木119-3-005-05: 明 治 16 年 8 月 3 日）に、聖上常御殿は「拾声間式分五厘」「拾三間」の「百四 拾六坪式合五勺小皇后宮常御殿は「九間」「拾間」の「九拾坪」と書加九て おり、これは竣工建物の床面皘（聖上常御殿: 146.13 坪、皇后宮常御殿 : 90 坪）とほほ一致する（但し聖上常御殿はいずれも 1 間 $=7$ 尺換算）。

14) 木子文庫所蔵图面から判断した。暖炉の設置位置についてはその後の変更 も見られる。

15）木子文庫所収の計画書（木119-3-005-1：明治 16 年 8 月 9日）に「第武区 三千六百 $O O$ 六坪戴合五勺 内千五百六拾式坪御廝ノ分」とあり、ここでは 第二区から厩の分を引いた床面糟を表宮殿の面楮とした。

16）『皇居御造営誌・皇居御造営経費顛末 決算之部壹』

17)『皇居御造営誌・巻之七』明治 18 年 5 月 29 日条、明治 19 年 12 月 21 日条、 費目についても同し。決算との差額は利息と考えられる。

18）『皇居御造営誌・巻之八』明治 21 年 10 月 8 日条

19) 『皇居御造営誌・巻之八』明治 21 年 9 月 25 日条

20) $r$ 二十二年竣工遷幸ヨ企望スルモノ八既二二十三年二於テ國會開設ノ大詔

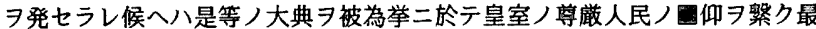
モ関係ヨ有スル大ナル事トス是年度 $\ni$ 期スル理由二候」(『皇居御造営誌・巻 之六』明治 16 年 2 月 12 日条）から、吹上宮殿計画ては、明治 23 年の国会開 設に間に合うように竣工時期が設定されたと考えられる。

21）『皇居御造営誌·皇居御造営経費顛末 予算之部壹』明治 18 年 3 月 17 日条 22)『皇居御造営誌·皇居御造営経責顛末 予算之部戴』明治 18 年 12 月 10 日条 23）『皇居御造営誌・巻之七』明治 17 年 5 月 7 日条

24）「別表月割図ノ通凡来ル二十年八月 7 以テ竣工可致見込二有之候」(『皇居 御造営誌・巻之七』明治 17 年 6 月 18 日条)

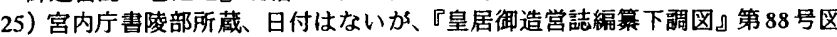
面（明治 17 年 4 月 14 日）と平面がほほ一致することから判断した。

26）『皇居造営銶・謁見所』所収、明治 18 年 8 月 2 日

27 『皇居造営録・謁見所』所収、明治 18 年 6 月 12 日
28）図面に定規をあてて湘った值

29）『皇居御造営誌・不材挽立事業』には、船輸送木材の最大寸法について「壱 尺角以上長三丈五尺五寸迄」と書かれている。

30）木子文庫所収「謁見所小屋組」（木085-1-003:明治 17年 8月 1 日）

31) 木子文庫所収「内謁見所正面二拾分一小屋組図」(木100-2-009:日付なし)、 梁間が 5.5 間であることなとから判断した。

32）木子文庫所收「第武区屋根色分之図」(木109-1-061：明治 17 年 6 月 27 日）

33）本稿第 3 章および註 39 参照

34）『皇居造営録・留宴所』所収、明治 17 年 8 月 11 日

35）『皇扂御造営誌・宮殿室内暖温機械据付事業』より、第一期（明治 19 年 5 月着工）として謁見所、劉宴所、後席之間、東西溜之間、内謁見所の6棵に 教設され、やや遅れて南溜之間に敷設（明治 20 年 3 月着工）された。

36)『皇居御造営誌・巻之七』明治 18 年 7 月 11 日条

37）謁見所の場合、明治 19 年 7〜 12月には月あたり $2.8 〜 2.9 \%$ 月あった作業 か、明治 20 年 1 月は $0 \% 、 2$ 月・3 月は $1 \%$ に留まっている。

38）『皇居御造営誌・巻之七』明治 19 年 9 月 30 日条

39）『皇居造営録』所收「築造仕法書」の作成時期は、謁見所が明治 18 年 7月、 嘢宴所が明治 18 年 6 月、後席之間が明治 18 年 6 月、東溜之間が明治 18 年 3 月、西溜之間が明治 18 年 5 月となっている。木工事着手の日付は、『皇居御 造営誌・巻之七』より、謁見所が明治 18 年9月 1 日、製宴所が明治 18 年 9 月 6 日、後席之間が明治 18 年 9 月 12 日、東西溜之間が明治 18 年 8 月 5 日と なっている。

40）『皇居御造営誌・東車寄』所収「受附之間及南北溜之間其他仕様書」には 「南北溜之間廊下トモ鞉摺高サ八寸上下栝見付戴重決り丸面取り」とあり、 この「靴摺」も同様にいわゆる巾木のことを指していると考えられる。

41）木子文車所取「謁見所入側戸口内面」（木099-2-001-11：明治 19 年 6 月 22 日)、「後席廣間之図」(史料番号・木 080-1-001: 明治 19 年 1 月 7 日)

42）『皇居造営録』所収の建具仕様書の作成時期は、謁見所が明治 20 年 2 月、 睤宴所が明治 20 年 3 月、後席之間が明治 20 年 4 月となっている。

43）『皇居造営録・雑品』第 37 巻所収「謁見所其他建具用硝子板伊理斯商社 1) 購入方ノ件」明治 20 年 3 月 3 日

44）『皇居造営録・片山技師独逸出張装飾品購買諸件』第 3 巻所収、明治 20 年 3 月 11 日から同年 10 月 5 日までの電報 73 通が収録されている。

45) 『皇居造営録・雑品』第 41 巻所収、明治 20 年 4 月 6 日加 万同年 6 月 29 日 まての笪報 29 通が収録されている。

46) 木子文庫所収「謁見所天井伏百分壱之図」（木 100-2-056: 明治 19 年 1 月 10 日）、謁見所天井伏因（無題）（木099-2-015-1・2：明治 19 年 4 月 11 日）、 および謁見所天井伏図（無題）(木100-2-058：日付なし）の3 点

47)『皇居造営録・謁見所』所取「謁見所格天井御模様替二付增減御入費調書小 明治 20 年 12 月

48）『皇居造営録・東溜之間・西溜之間』所収、明治 19 年 10 月

49）『皇居造営録・東溜之間・西溜之間』所収、明治 20 年 3 月

50)「入側鴨居下端唐戸面取り小「欄間敷居鴨居方立共唐戸面取」と書かれて いる(『皇居御造営誌・謁見所』など)。

51）『皇居造営録・東溜之間・西溜之間』所収「西溜之間御模様换臨時工事增 減差引增御入費」(明治 19 年 12 月 21 日) ・ 「東溜之間御模様換臨時工事御入 費」(明治 19 年 12 月 21 日)

52）『皇居御造営誌・家具装置事業』第 1 巻

53) 『皇居御造営誌・巻之七』明治 20 年 5 月 12 日条

54)『皇居御造営誌・各種織物事業』明治 19 年 7 月 22 日条

55 )『皇居造営録・雑品』第 22 巻所収、明治 19 年 7 月 20 日

56)『皇居御造営誌・各種織物事業』明治 20 年 5 月 12 日条

57）お札と切手の博物館所蔵

58）『皇居御造営誌・天井張打出紙其他製紙事業及、明治 20 年 10 月 18 日采

59）「お札と切手の博物館」には明治宮殿の壁紙として伝わる金唐革紙製の壁 紙が保存されている。この壁紙については、久米康生「明治の“芸術産業” 金唐革紙」(『きんからかわ 革と紙の東西交流』INA BOOKLET、昭和 59年、 p.55)、久米康生『彩飾和紙譜』（平凡社、平成 6 年、p.176）に詳しい。

60)『皇居御造営誌・巻之八』明治 21 年 10 月 10 日条

61）中村圭介『文明開化と明治の住まい-暮らしとインテリアの近代史（上）-』 (理工学社、平成 12 年) 第 2 章第 3 節 (p.63)

62）『皇居御造営誌・家具装置事業』所収、いずれも日付なし

63）『皇居造営録・片山技師独逸出張装飾品購買諸件』第 1 巻所収「装飾品説 明書同内訳書」および「独逸國工注文装飾品約定原書写」

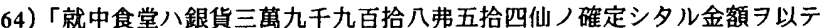
十ヶ月内二東京二於テ交付スベキ注文ヨアリ残余ノ家具八片山出仕欧洲へ着 人上爱二附添スル所ノ原計算書二基キ同出仕力必要卜思考スル所八之二增減 ヨ行ヒ十二ヶ月内二東京二於テ交付スルノ定約 具装置事業第壹』所収「定約書」)

65）『明治天皇紀』によれば、朝儀の参加者は親王、公爵、大臣、親任官、勅 任官、鲫香間祇候、各国公使など天皇側近に限られていたと考えられる。大 典では、最も規模の大きい皇太子御成婚の礼で、皇族、大墨位以下一等以上、 各国公使、貿二等、勅任官、有爵者、奏任官三等以下五等以上とその夫人が 招かれ、晚餐会は繁宴所に 1200 人、後席の間広間に 150 人、東溜之間に 650 人と、䙬数の殿吕にわけて行われたと記されている。

66)宮内䀶·伊藤博文の宮中夜会に対寸る関心の高さについては、坂本一登『伊 藤博文と明治国家形成・『宮中』の制度化と立䕒制の導入-』（吉川弘文館、平 成 3 年）第二章第二節および第三章第三節に詳しい。 